\title{
How the diversity, abundance, size and climbing mechanisms of woody lianas are related to biotic and abiotic factors in a subtropical secondary forest, Taiwan
}

\author{
Sheng-Zehn Yang • Hsuan Fan • Kuan-Wei Li • \\ Teng-Yao Ko
}

Received: 3 November 2016/ Revised: 00 Month 0000 / Accepted: 20 October 2017 / Published online: 8 January 2018

(C) The Author(s) 2018. This article is an open access publication

\begin{abstract}
Lianas are woody vines that play an important role in forest dynamics in tropical and subtropical areas. Their relationship to various biotic and abiotic conditions is, however, not yet wholly clear. We explored how the size, climbing mechanisms, diversity and abundance of woody lianas is related to host plant size, environmental factors and topography. Liana assemblages were examined in twenty $20 \times 20 \mathrm{~m}$ plots in each of three topographic sites (valley, slope and ridge) in a subtropical secondary forest in southeastern Taiwan. The valley site had the highest abundance and species richness of lianas. The abiotic factors, soil $\mathrm{pH}$ and rock cover, were related to different topographic sites. Larger lianas were always found on larger host trees, while smaller lianas were found in smaller trees; no lianas with a DBH greater than $10 \mathrm{~cm}$ were found. Significantly more adhesive lianas were found on larger trees whereas twining and leaning-hook lianas were found in smaller trees. In conclusion, this study demonstrates that the species of liana is associated with the size and type of tree growing under different topographic conditions.
\end{abstract}

S.-Z. Yang $(\bowtie) \cdot$ H. Fan $\cdot$ K.-W. Li

Department of Forestry, National Pingtung University of Science and Technology, Neipu, Pingtung, Taiwan

e-mail: yangsz@mail.npust.edu.tw

T.-Y. Ko

Hengchun Ranger Station, Pingtung Forest District Office, Taiwan Forestry Bureau, Hengchun, Pingtung, Taiwan
Keywords Climbing $\cdot$ Host tree $\cdot$ Liana $\cdot$ Rarefaction . Species richness $\cdot$ Topography

\section{Introduction}

Woody lianas constitute an important part of tropical and subtropical forests (Schnitzer and Bongers 2002) and represent special evolutionary adaptations driven by competition for light (Tang et al. 2012). Their thin stems relying on the support of trees, wide vessels, poor secondary thickening, special adaptations for climbing, deep roots and high leaf area (Putz 1983) distinguish woody lianas from trees. They influence forest gap dynamics, increase the forest turnover rate and reduce forest recruitment, growth rate and biomass (Hegarty and Caballé 1991; Schnitzer and Bongers 2002, 2011). Most tropical and subtropical lowland and montane forests harbour several liana species; their distribution and performance is, however, affected by different biotic and abiotic factors.

Several environmental factors are correlated with abundance and distribution patterns of lianas across abiotic gradients. For example, the abundance and diversity of lianas decreases with decreasing rainfall and temperature (Parthasarathy et al. 2004; Schnitzer 2005). Various soil properties (such as soil type, soil pH, fertility and phosphorus concentration) might also affect the species richness of lianas (Nurfazliza et al. 2012). Topographic position and natural disturbances that produce tree-fall gaps might affect the diversity and regeneration of lianas (Letcher and Chazdon 2009). 
The distribution of lianas might also be influenced by a range of biotic factors, such as invading species decrease the abundance of linans (Addo-Fordjour et al. 2009); larger host trees support a larger diversity of liana species and increase the basal areas of lianas (Homeier et al. 2010). Host tree availability is one of the factors which limit liana growth and is related to the attachment mechanisms of lianas (Putz 1984; Isnard and Silk 2009). Lastly, human disturbance may increase the cover of lianas of the host tree canopy and wind dispersal of seeds (Schnitzer and Bongers 2011).

Much of the information about the relationship between lianas, topography and soil conditions and lianatree interactions described above has been collected in tropical forests. However, information about the relationship of lianas to different habitats and host trees in subtropical forests remains limited, especially in Taiwan. In particular, studies assessing the relationship between liana size and climbing mechanisms and the diameter and height of host trees or whether topography affects the distribution and abundance of lianas in southeastern Taiwan are still few and unclear.

Our objective was to determine how diversity, abundance, size and climbing mechanisms of woody lianas in a subtropical forest are related to biotic and abiotic factors. The following questions were investigated: (1) What is the diversity and abundance of lianas in the area under study? (2) How are the diversity, abundance and size of lianas affected by topography and other abiotic factors? (3) How are the size and climbing mechanisms of lianas related to the size of host trees? We conducted our study in a secondary subtropical forest in southeastern Taiwan which hosts 35\% of 133 liana species documented in Taiwan to date (Yang et al. 2015).

\section{Material and methods}

\section{Study area}

The study area was located in the Tajen Experimental Forest Station $\left(22^{\circ} 15^{\prime} \mathrm{N}, 120^{\circ} 49^{\prime} \mathrm{E}\right)$ at the boundary between the Pingtung and Taitung counties of Taiwan. The study area covered an area of 576 ha, with elevations ranging from 180 to $900 \mathrm{~m}$ a.s.l. (Fig. 1). This area lies within the southeastern climate region and has an annual rainfall of ca $3,500 \mathrm{~mm}$, a mean annual temperature of around $20^{\circ} \mathrm{C}$ and no significant dry season. Due to the south-west monsoon in the summer and the northeast monsoon in the winter, precipitation occurs throughout the year. The dominant native tree species include: Alniphyllum pterospermum, Beilschmiedia tsangii, Castanopsis cuspidata var. carlesii, Cyclobalanopsis championii, Machilus japonica var. kusanoi and Schima superba var. kankaoensis (Yang et al. 2015). This area was clear-cut by intense logging activities in the early 1970s and was reforested between 1975 and 1981. The tree species that were planted
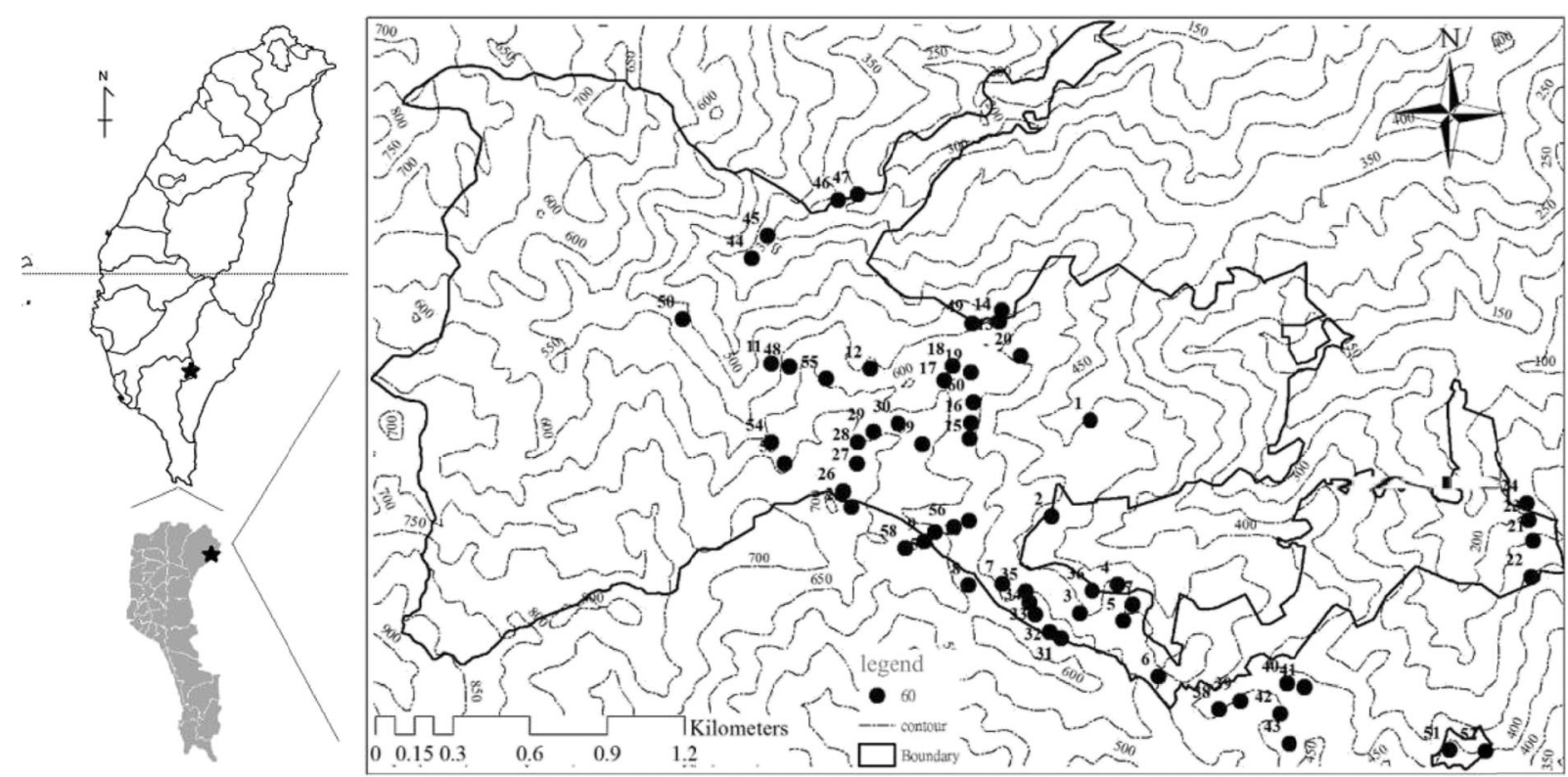

Fig. 1 Map of southern Taitung County showing the location of 60 liana plots at the Tajen Experimental Forest Station, Taiwan 
Table 1 Only top ten species of tree and liana are shown about their frequency, average diameter at breast height (DBH), basal areas and largest DBH

\begin{tabular}{|c|c|c|c|c|c|}
\hline Species & Family & $\begin{array}{l}\text { Frequency } \\
{[\%]}\end{array}$ & $\begin{array}{l}\text { Average DBH } \\
{[\mathrm{cm}]}\end{array}$ & $\begin{array}{l}\text { Basal area } \\
{\left[\mathrm{m}^{2} \cdot \mathrm{ha}^{-1}\right]}\end{array}$ & $\begin{array}{l}\text { Largest DBH } \\
{[\mathrm{cm}]}\end{array}$ \\
\hline \multicolumn{6}{|l|}{ Trees } \\
\hline Castanopsis cuspidata var. carlesii & Fagaceae & 9.5 & - & 3.21 & - \\
\hline Schefflera octophylla & Araliaceae & 8.6 & - & 2.99 & 51 \\
\hline Schima superba var. kankaoensis & Theaceae & 4.1 & - & 1.33 & - \\
\hline Adinandra formosana & Theaceae & 4.1 & - & - & - \\
\hline Cyclobalanopsis longinux & Fagaceae & 3.4 & - & - & - \\
\hline Albizia falcata & Fabaceae & - & 35.8 & - & 53 \\
\hline Alniphyllum pterospermum & Styracaceae & - & 27.9 & - & - \\
\hline Sapium discolor & Euphorbiaceae & - & 27.7 & - & - \\
\hline Castanopsis fabri & Fagaceae & - & 27.1 & 1.89 & 94 \\
\hline Machilus zuihoensis & Lauraceae & - & 24.4 & - & - \\
\hline Aleurites montana & Euphorbiaceae & - & - & 1.44 & - \\
\hline Lagerstroemia subcostata & Lythraceae & - & - & - & 70 \\
\hline Bischofia javanica & Euphorbiaceae & - & - & - & 64 \\
\hline \multicolumn{6}{|l|}{ Lianas } \\
\hline Mussaenda pubescens & Rubiaceae & 10.3 & - & 0.018 & - \\
\hline Stauntonia obovatifoliola & Lardizabalaceae & 7.5 & - & - & - \\
\hline Calamus formosanus & Arecaceae & 6.5 & 2.6 & 0.043 & - \\
\hline Erycibe henryi & Convolvulaceae & 5.8 & & & \\
\hline Zanthoxylum nitidum & Rutaceae & 4.8 & & 0.018 & \\
\hline Hiptage benghalensis & Malpighiaceae & - & 3.0 & - & - \\
\hline Morinda umbellate & Rubiaceae & - & 2.7 & 0.040 & 8.0 \\
\hline Ampelopsis brevipedunculata var. hancei & Vitaceae & - & 2.6 & - & - \\
\hline Erycibe henryi & Convolvulaceae & - & 2.2 & 0.031 & - \\
\hline Kadsura japonica & Schisandraceae & - & - & - & 9.1 \\
\hline Tetrastigma formosanum & Vitaceae & - & - & - & 8.8 \\
\hline Tetrastigma umbellatum & Vitaceae & - & - & - & 8.8 \\
\hline Fissistigma glaucescens & Annonaceae & - & - & - & 8.0 \\
\hline
\end{tabular}

included: Albizia falcata, Aleurites montana, Alnus formosana, Fraxinus griffithii and Liquidambar formosana. However, few of these species remain today. After 35 years regrowth by 2016, this area had become a secondary forest that had self-regenerated with regional native species.

\section{Field investigations}

Few studies have assessed which biotic and abiotic factors affect the diversity and distribution of lianas in southeastern Taiwan. We examined the distribution of lianas in three sites with different topography (ridge,
Table 2 Species richness, abundance, basal area and average diameter at breast height (DBH) of lianas in valley, slope and ridge habitats

\begin{tabular}{lllll}
\hline Habitats & $\begin{array}{l}\text { Species } \\
\text { richness }\end{array}$ & $\begin{array}{l}\text { Abundance } \\
{[\text { individuals } / 0.8 \mathrm{ha}]}\end{array}$ & $\begin{array}{l}\text { Basal area } \\
{\left[\mathrm{cm}^{2} / 0.8 \mathrm{ha}\right]}\end{array}$ & $\begin{array}{l}\text { Average } \\
\text { DBH [cm }]\end{array}$ \\
\hline Valley & 42 & 728.0 & $1,878.89$ & 1.53 \\
Slope & 39 & 359.0 & $2,068.98$ & 1.63 \\
Ridge & 29 & 529.0 & $1,206.34$ & 1.32 \\
\hline
\end{tabular}


Table 3 Density [individuals $/ 0.04$ ha] and important index values (IVI) of liana species (DBH $\geqq 0.5 \mathrm{~cm}$ ) distributed in valley, slope and ridge habitats

\begin{tabular}{|c|c|c|c|c|c|c|}
\hline \multirow[t]{2}{*}{ Scientific name } & \multicolumn{2}{|l|}{ Valley } & \multicolumn{2}{|l|}{ Slope } & \multicolumn{2}{|l|}{ Ridge } \\
\hline & Density & IVI & Density & IVI & Density & IVI \\
\hline Mussaenda pubescens & 70 & 27.7 & 112 & 37.5 & 73 & 41.6 \\
\hline Stauntonia obovatifoliola & 53 & 24.9 & 69 & 22.4 & 41 & 26.7 \\
\hline Erycibe henryi & 34 & 19.7 & 39 & 19.0 & 29 & 31.7 \\
\hline Morinda umbellata & 31 & 19.5 & 47 & 24.3 & 25 & 36.1 \\
\hline Derris laxiflora & 12 & 15.5 & 2 & 0.9 & 7 & 8.4 \\
\hline Fissistigma glaucescens & 23 & 13.3 & 57 & 24.4 & 20 & 21.9 \\
\hline Hiptage benghalensis & 13 & 12.3 & 1 & 0.9 & 9 & 8.4 \\
\hline Cayratia corniculata & 25 & 11.9 & 17 & 6.6 & & \\
\hline Zanthoxylum nitidum & 21 & 11.4 & 43 & 21.2 & 17 & 15.9 \\
\hline Tetrastigma formosanum & 23 & 11.1 & 33 & 12.3 & 2 & 1.6 \\
\hline Ampelopsis brevipedunculata & 15 & 10.5 & 2 & 1.4 & & \\
\hline Kadsura japonica & 18 & 10.2 & 19 & 10.3 & 3 & 3.3 \\
\hline Ventilago elegans & 13 & 8.2 & 2 & 1.4 & 1 & 1.0 \\
\hline Anodendron affine & 14 & 8.1 & 27 & 12.7 & 28 & 25.1 \\
\hline Actinidia callosa & 7 & 7.4 & 23 & 13.6 & 3 & 3.7 \\
\hline Piper taiwanense & 13 & 7.1 & 8 & 3.6 & 9 & 7.3 \\
\hline Anodendron benthamiana & 12 & 7.1 & 15 & 7.6 & 6 & 6.0 \\
\hline Rubus pyrifolius & 14 & 6.7 & 14 & 7.0 & & \\
\hline Psychotria serpens & 14 & 5.6 & 41 & 12.6 & 46 & 27.1 \\
\hline Pileostegia viburnoides & 8 & 5.3 & 12 & 4.6 & 1 & 1.1 \\
\hline Trachelospermum gracilipes & 12 & 5.3 & 38 & 10.9 & 11 & 7.6 \\
\hline Pueraria montana & 11 & 5.0 & 3 & 2.0 & 1 & 1.2 \\
\hline Celastrus kusanoi & 6 & 4.8 & 1 & 0.6 & 1 & 1.2 \\
\hline Bauhinia championii & 5 & 4.5 & & & & \\
\hline Melodinus angustifolius & 7 & 4.3 & & & & \\
\hline Eleutherococcus trifoliatus & 9 & 4.2 & & & & \\
\hline Zanthoxylum scandens & 5 & 3.7 & 4 & 2.7 & & \\
\hline Ecdysanthera rosea & 4 & 3.6 & & & & \\
\hline Ficus aurantiaca var. parvifolia & 7 & 3.3 & 12 & 5.7 & 1 & 1.0 \\
\hline Cayratia japonica & 5 & 3.0 & & & & \\
\hline Mikania micrantha & 5 & 2.9 & 3 & 1.0 & 2 & 1.6 \\
\hline Marsdenia tinctoria & 4 & 2.8 & 1 & 0.6 & & \\
\hline Clematis uncinata & 2 & 1.4 & & & & \\
\hline Polygonum multiflorum var. hypoleucum & 4 & 1.3 & & & & \\
\hline Ipomoea cairica & 2 & 1.3 & & & & \\
\hline Gymnema sylvestre & 1 & 0.9 & & & & \\
\hline Coptosapelta diffusa & 2 & 0.9 & 3 & 1.8 & 2 & 2.0 \\
\hline Stauntonia obovata & 1 & 0.7 & 20 & 6.5 & 8 & 5.7 \\
\hline Paracyclea ochiaiana & 1 & 0.7 & & & & \\
\hline Uncaria lanosa var. appendiculata & 1 & 0.7 & & & & \\
\hline Vernonia gratiosa & 1 & 0.7 & & & & \\
\hline Strychnos cathayensis & 1 & 0.7 & 8 & 3.7 & 3 & 3.6 \\
\hline
\end{tabular}


Table 3 (continued)

\begin{tabular}{|c|c|c|c|c|c|c|}
\hline \multirow[t]{2}{*}{ Scientific name } & \multicolumn{2}{|l|}{ Valley } & \multicolumn{2}{|l|}{ Slope } & \multicolumn{2}{|l|}{ Ridge } \\
\hline & Density & IVI & Density & IVI & Density & IVI \\
\hline Mucuna macrocarpa & & & 27 & 8.8 & 1 & 1.1 \\
\hline Aeschynanthus acuminatus & & & 16 & 5.9 & 4 & 2.8 \\
\hline Elaeagnus glabra & & & 3 & 2.2 & 3 & 3.4 \\
\hline Aristolochia cucurbitifolia & & & 1 & 0.7 & & \\
\hline Capparis sikkimensis subsp. formosana & & & 1 & 0.6 & & \\
\hline Ecdysanthera utilis & & & 1 & 0.6 & & \\
\hline Ficus sarmentosa var. nipponica & & & 1 & 0.6 & 2 & 2.0 \\
\hline Passiflora suberosa & & & 1 & 0.6 & & \\
\hline Clematis akoensis & & & 1 & 0.6 & & \\
\hline Total individuals & 728 & & 359 & & 529 & \\
\hline Species numbers & 42 & & 39 & & 29 & \\
\hline
\end{tabular}

slope and valley) to elucidate the relationships between lianas and host trees under different conditions. The ridge and valley sites were located in a secondary forest where lianas are abundant. They were selected using a contour map based on their elevational ranges and were located using the Global Positioning System. A slope of the same aspect was chosen because it was located between the ridge and the valley. Areas from different topographic categories, but with similar elevations, were selected to increase sampling homogeneity. Within each topography type, 20 plots of vegetation were surveyed, each covering a standard area of $400 \mathrm{~m}^{2}(20 \mathrm{~m} \times 20 \mathrm{~m})$. The plots were separated by a minimum distance of approximately $200 \mathrm{~m}$. Within each plot, a $100 \mathrm{~m}^{2}$ $(10 \mathrm{~m} \times 10 \mathrm{~m})$ sub-plot was surveyed to reveal interspecific associations between host tree species

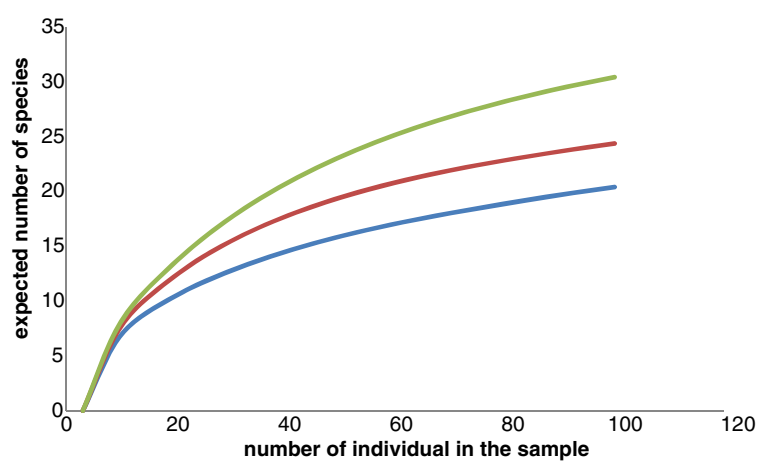

Fig. 2 Rarefaction curves for the diversity of lianas in three different habitats. There were 728 individuals of 42 species in the valley, 359 individuals of 39 species on the slope and 529 individuals of 29 species on the ridge and liana species and were evaluated for pairs of trees and lianas. A total of 60 plots $(2.4$ ha) were sampled from August 2013 to March 2014.

In each plot, eight abiotic variables were measured during the study period, namely altitude, stoniness percentage, outcropping rock cover percentage, soil $\mathrm{pH}$, soil water percentage, available soil phosphorus, slope and aspect. In each plot, a topsoil sample $(0-20 \mathrm{~cm})$ was collected from each corner and from the center of the plot. These five samples were combined and used to analyse available phosphorus (P), moisture and $\mathrm{pH}$ (Malizia et al. 2009). Soil analyses were carried out at the Soil Laboratory, Department of Environmental Science and Engineering, National Pingtung University of

Table 4 Significant abiotic factors determined by forward selection in a Monte Carlo permutation test

\begin{tabular}{llll}
\hline Environmental factors & $\lambda_{\mathrm{A}}$ & $P$ & $F$ \\
\hline Soil pH & 0.30 & $0.002^{* *}$ & 4.93 \\
Elevation & 0.12 & $0.002^{* *}$ & 2.05 \\
Aspect & 0.10 & $0.008^{* *}$ & 1.67 \\
Rock cover ratio & 0.09 & $0.036^{*}$ & 1.55 \\
Available soil phosphorus [ppm] & 0.06 & 0.224 & 1.20 \\
Slope & 0.07 & 0.142 & 1.22 \\
Soil water percentage [\%] & 0.04 & 0.888 & 0.72
\end{tabular}

Note: $* * P<0.005 ; * P<0.05 . \lambda_{\mathrm{A}}-$ increase in eigenvalue. Conditional effects of the Monte Carlo permutation test were performed and each environmental variable as an additional environmental variables 
Table 5 Variation decomposition of the effect of three groups of explanatory variables with adjusted covariates

\begin{tabular}{lllrrr}
\hline Components & Source & $\begin{array}{l}\text { Explained } \\
\text { variation }\end{array}$ & $\%$ of all & $D . f$. & $\begin{array}{l}\text { Mean } \\
\text { square }\end{array}$ \\
\hline a & Unique topographical site & 0.042 & 1.1 & 1 & 0.094 \\
$\mathrm{~b}$ & Unique abiotic factors & 0.451 & 11.9 & 4 & 0.163 \\
$\mathrm{c}$ & Unique host stem DBH & 0.019 & 0.5 & 1 & 0.072 \\
$\mathrm{~d}$ & Shared & 0.063 & 1.6 & & \\
$\mathrm{e}$ & Residual & 3.230 & 84.9 & & \\
Total & & 3.805 & 100.0 & & \\
\hline
\end{tabular}

Science and Technology, Taiwan. Available P was determined by spectrophotometry after Bray P1 extractions for acidic soils (Bray and Kurtz 1945). Soil moisture (\%) was determined by oven-drying fresh soil samples $(50 \mathrm{~g})$ at $105^{\circ} \mathrm{C}$, until a constant weight was obtained and then comparing wet and dry weights. Soil $\mathrm{pH}$ was measured by using a $\mathrm{pH}$ meter with a glass electrode (Jenway 3305; Jenway, UK) in a 1:2 soil:water ratio. Altitude and slope were measured in each plot using a GPS device (Garmin Oregon 550t; Garmin, Lenexa, KS, USA) and a clinometer (Suunto SPUME-5/360PC; Suunto, Finland), respectively. Aspect was measured using an azimuth unit and a compass, and the azimuth was converted into an aspect-moisture gradient index (Day and Monk 1974). The percentage of stoniness and rock cover in each plot was recorded, along with the percentage of stones with a diameter of less than $30 \mathrm{~cm}$ and larger than $30 \mathrm{~cm}$, respectively.

Lianas included all woody vines. Vertical vegetation structures were the tree layer (height $>6 \mathrm{~m}$ ), shrub layer (height $0.5-6 \mathrm{~m}$ ) and herb layer (height $<0.5 \mathrm{~m}$ ). Species richness, the coverage of each species and the layer to which each species belonged were recorded for each plot. Relative species cover was estimated using the Braun-Blanquet abundance-coverage scale (modified from van der Maarel 1979). Species richness, abundance, average DBH and basal area of lianas were measured in each plot. The species richness value and ShannonWeaver index (Magurran 1988) were measured to determine the diversity of lianas at the plot level. The important value index (IVI) of each liana species was measured at the topographic site level. In each sub-plot, all living trees and shrubs $>5 \mathrm{~cm}$ in DBH, all living lianas $>0.5 \mathrm{~cm}$ diameter (1.3 $\mathrm{m}$ from the ground surface; hereafter $\mathrm{DBH}$ ), the DBH of host trees on which lianas grew, and the liana climbing types were also recorded. The diameter of lianas was divided into three classes (n1: $0.5-3.0$ $\mathrm{cm}$; $\mathrm{n} 2$ : $3.1-6 \mathrm{~cm}$; $\mathrm{n} 3: 6.1-10 \mathrm{~cm}$ ). The census of all living lianas followed the protocol of Schnitzer et al. (2006). The climbing mechanisms of lianas (adhesive, hook, or twining) followed Isnard and

Table 6 Comparison among abiotic factors and biotic factors relative to lianas in valley, slope and ridge habitats

\begin{tabular}{lccc}
\hline Abiotic and biotic variables & \multicolumn{2}{l}{ Habitats } & \\
\cline { 2 - 4 } & \multicolumn{1}{l}{ Valley } & Slope & Ridge \\
\hline Soil pH & $4.92^{\mathrm{b}} \pm 0.8$ & $4.42^{\mathrm{a}} \pm 0.4$ & $4.21^{\mathrm{a}} \pm 0.1$ \\
Alt & $496.6^{\mathrm{a}} \pm 99.0$ & $518.85^{\mathrm{a}} \pm 122.1$ & $621.55^{\mathrm{b}} \pm 52.3$ \\
Rock cove ratio [\%] & $11.8^{\mathrm{b}} \pm 14.9$ & $7.9^{\mathrm{ab}} \pm 9.6$ & $1.70^{\mathrm{a}} \pm 2.3$ \\
Aspect & $5.7^{\mathrm{a}} \pm 1.6$ & $5.8^{\mathrm{a}} \pm 2.0$ & $6.5^{\mathrm{a}} \pm 2.0$ \\
Species richness* & $11.15^{\mathrm{b}} \pm 0.65$ & $11.70^{\mathrm{b}} \pm 0.54$ & $7.25^{\mathrm{a}} \pm 0.44$ \\
Abundance* & $26.45^{\mathrm{b}} \pm 1.64$ & $36.40^{\mathrm{c}} \pm 2.36$ & $17.95^{\mathrm{a}} \pm 1.25$ \\
Basal area* & $33.45^{\mathrm{b}} \pm 2.78$ & $42.28^{\mathrm{b}} \pm 3.06$ & $20.76^{\mathrm{a}} \pm 2.23$ \\
Shannon-Weaver index $\left(H^{\prime}\right)^{*}$ & $0.93^{\mathrm{b}} \pm 0.02$ & $0.94^{\mathrm{b}} \pm 0.02$ & $0.75^{\mathrm{a}} \pm 0.04$ \\
\hline
\end{tabular}

Note: Mean values $( \pm S D)$ with different superscripts within a row are significantly different $(*: P<0.05$, **: $P<0.01)$ according to Tukey's HSD test 


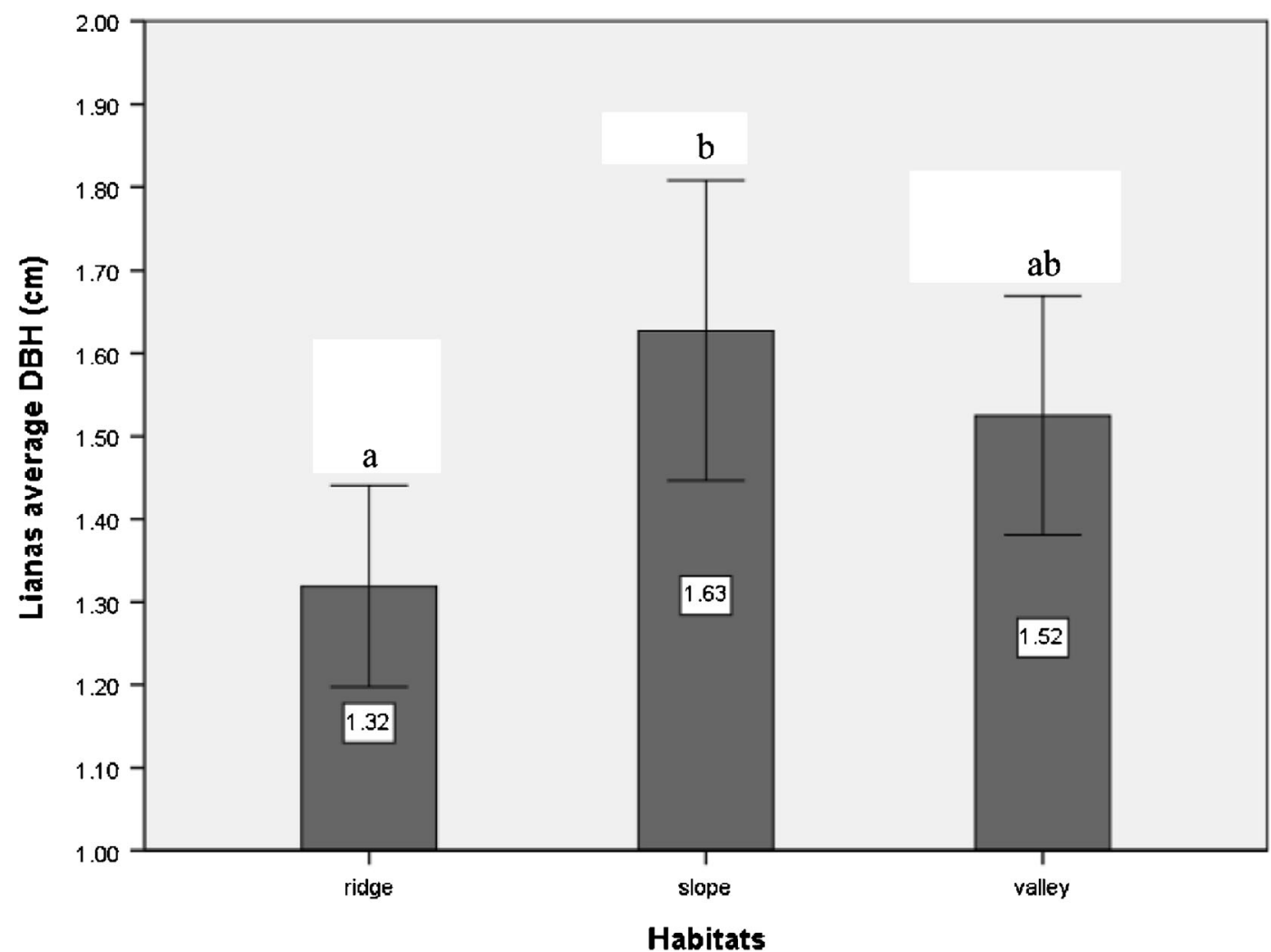

Fig. 3 Average diameter at breast height (DBH) of lianas in three different habitats. Means without the same letter above the bars are significantly different at the $5 \%$ level according to Tukey's HSD test

Silk (2009). For the top ten species, the frequency $(\%)$, average $\mathrm{DBH}(\mathrm{cm})$ and basal area $\left(\mathrm{m}^{2} / \mathrm{ha}\right)$ of lianas and trees were recorded in all three sites. The nomenclature of all vascular plants followed Boufford et al. (2003). Voucher specimens were deposited in the PPI Herbarium, Department of Forestry, National Pingtung University of Science and Technology, Taiwan.

\section{Statistics}

As species richness is highly correlated with abundance, we performed a rarefaction analysis (Magurran 1988) to rarefy to the lowest number of liana individuals among plots and, thus, correct for this bias. To reduce collinearity among environmental variables, canonical correspondence analysis (CCA) was used. In CCA, forward stepwise selection with a Monte Carlo permutation test (ter Braak and Šmilauer 2012) is able to determine which variables are actually independent of one another, so they may be incorporated into an analysis. To test the unique effects of abiotic factors, the liana community compositions was used as the response, while three predictor groups (topographical site, abiotic predictors with a stepwise selection and host stem DBH) were used to perform variation partitioning analyses (ter Braak and Šmilauer 2012). Statistical tests were performed using SPSS (version 20.0; Norusis 2011). One-way ANOVA was used to analyse the results for the average DBH, climbing mechanisms and DBH class of lianas associated with topographic sites, along with host tree DBH and significant environmental factors. Between-group comparisons were performed using Tukey's HSD test to clarify significant differences between sites.

\section{Results}

Altogether we recorded 84 liana species in our study. The families with the greatest number of liana species were Apocynaceae (5), Asclepiadaceae (5), Menispermaceae (5) and Rubiaceae (5), see Appendix 1. No lianas with a DBH greater than $10 \mathrm{~cm}$ were found in the study plots. The lianas with the largest DBH was 


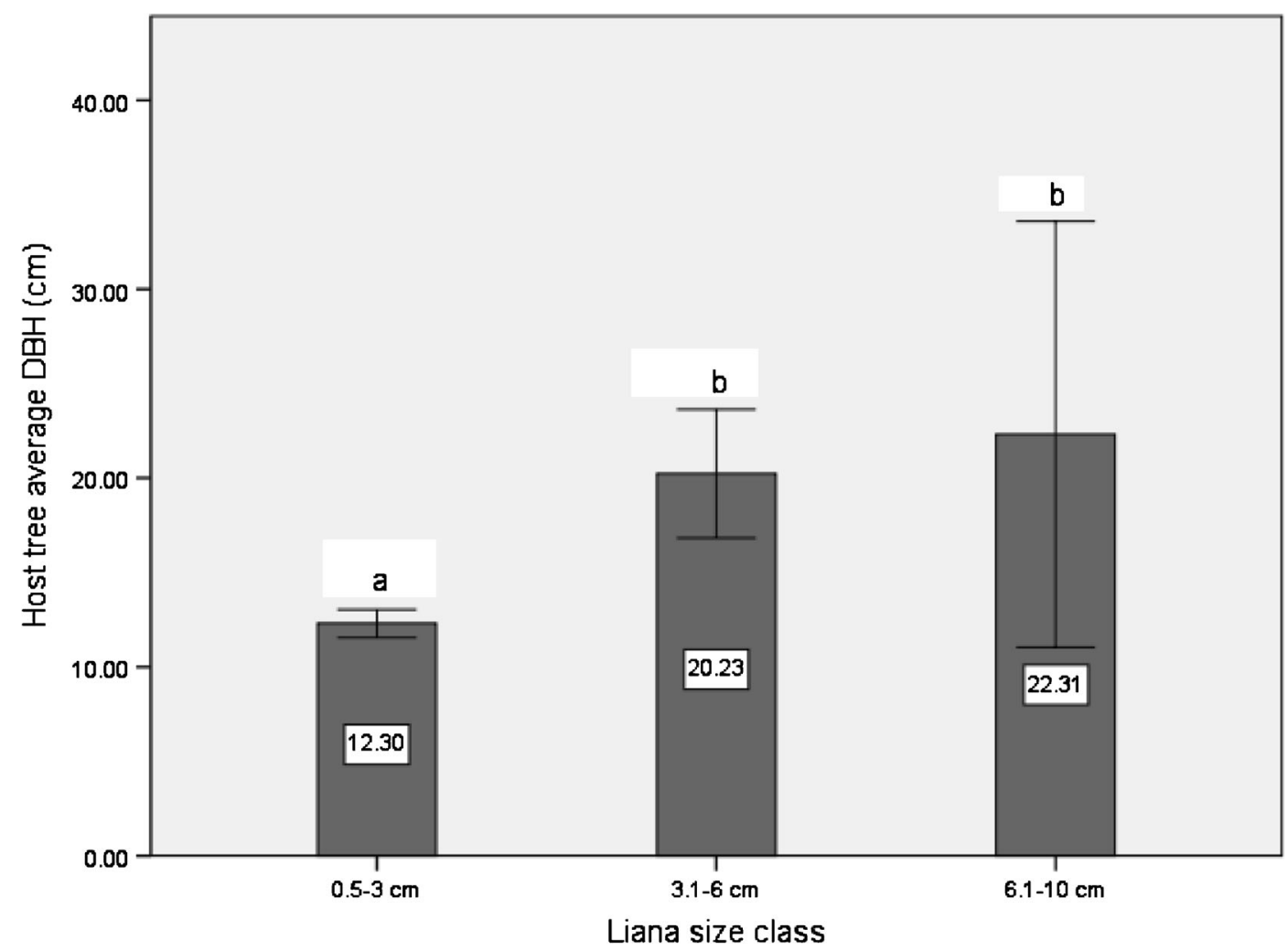

Fig. 4 Host tree average DBH for three different liana sizes. Means without the same letter above bars are significantly different at the 5\% level according to Tukey's HSD test

Kadsura japonica (Schisandraceae) $-9.1 \mathrm{~cm}$. Calamus formosanus (Arecaceae), a rattan species, was one of the most important lianas, based on its high frequency, above-average DBH and high basal area (the highest in the study - Table 1). The species accumulations curves showed that both the richness and abundance of liana species varied significantly with topography (Table 2,3). The highest abundance and richness of woody lianas were recorded in the valley site, followed by the slope and ridge sites (Fig. 2).

Four variables (soil $\mathrm{pH}$, altitude, aspect and rock cover) were found to be truly independent (Table 4). The variation partitioning results for the three predictor groups in analysis showed that each group had a unique effect, with overlap occurring in their explanatory power. The effect of explained variation of the major abiotic factors (such as altitude, soil $\mathrm{pH}$, rock cover and aspect) was more than the other covariates (such as topography and host stem DBH - Table 5) in liana diversity/ abundance and assemblage composition. This test showed that soil $\mathrm{pH}$ and rock cover gradually decreased along the topographical gradient from the valley to the ridge, but increased with altitude (Table 6). The average DBH of lianas was lowest in the ridge site (ANOVA, $F$ $=4.13 ; P<0.01$ ) and the largest in the slope site (Fig. 3 ). The differences recorded across the three sites might be related to these soil properties (Table 6).

The diameter of the liana classes significantly differed with the DBH of host trees (ANOVA, $F=17.19$; $P<0.01$ ), with larger trees supporting larger lianas (Fig. 4). The climbing mechanisms of the lianas significantly varied with the DBH of host trees (ANOVA, $F=18.46 ; P<0.01)$; for instance, adhering lianas were found in larger host trees whereas more twining and leaning lianas were found in smaller host trees (Fig. 5).

\section{Discussion}

Different topographic sites varied in the abundance and species richness of lianas, the abiotic factors soil $\mathrm{pH}$ and 


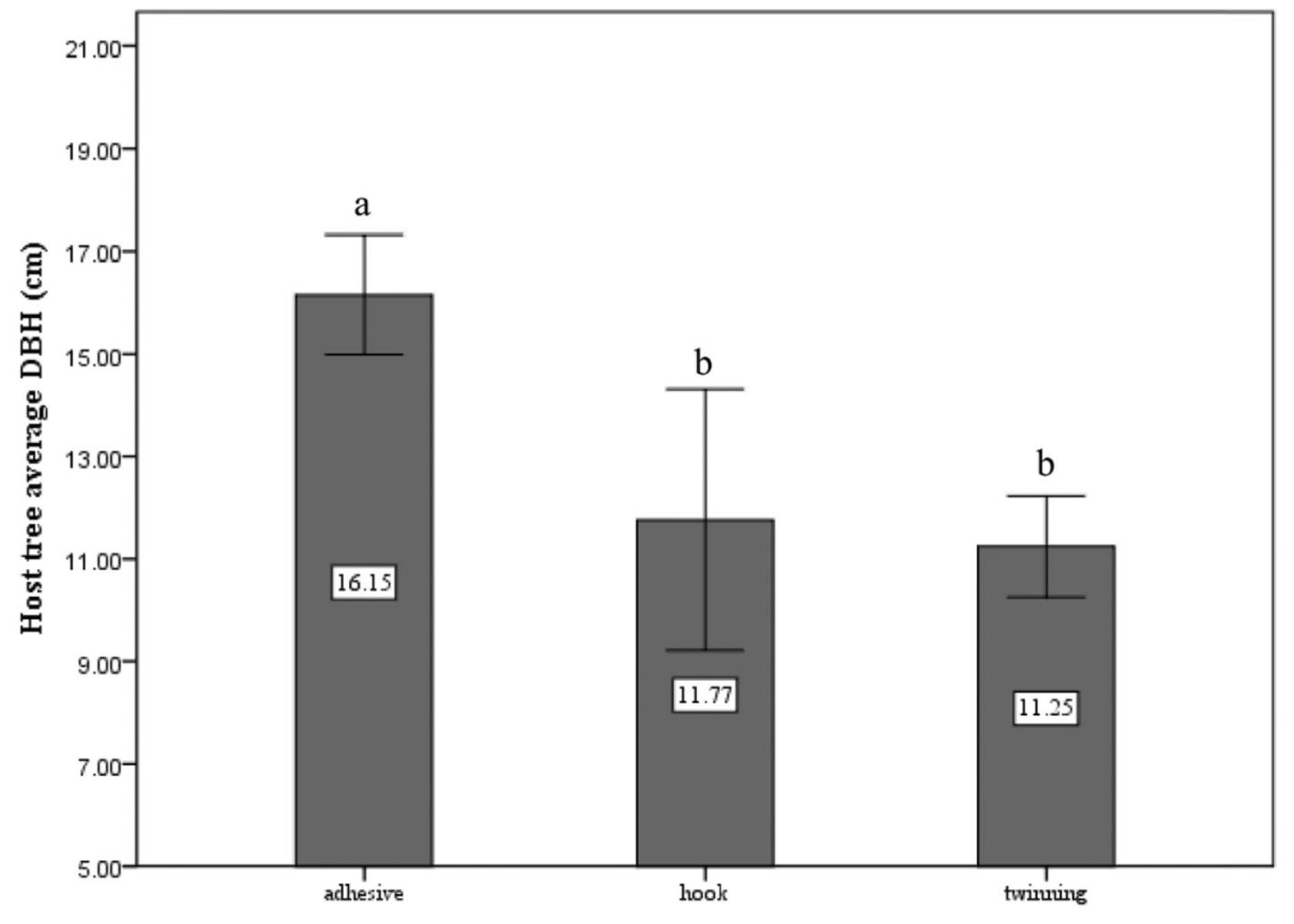

Liana climbing mechanism

Fig. 5 Host tree average DBH for three different liana climbing types. Means without the same letter above bars are significantly different at the $5 \%$ level according to Tukey's HSD test

rock cover were related to different topographic sites, and the diverse lianas with different climbing mechanisms were associated with the size and type of tree.

The family Apocynaceae was the most speciesrich liana family detected in this study, supporting the findings of studies conducted in other tropical forests (Addo-Fordjour et al. 2009). The winged morphology of its seeds increases the chance of it spreading to more areas, which might confer a reproductive advantage over other species of lianas (Wright et al. 2007).

The average DBH of lianas was smallest at the ridge site, even though some individuals of lianas at the ridge site were larger than those at the slope site (Table 2). This finding was similar to the results of a previous study in a tropical forest in Ecuador (Homeier et al. 2010). This previous study showed that an increase in elevation was not directly associated with a reduction in liana dominance, because even though the mean liana DBH decreased, the number of individuals increased. The Tajen Experimental Forest Station area is close to the coast, with the ridge site being affected by strong winds; thus, it is possible that many small lianas were found there, rather than a few large ones.

In the present investigation, soil $\mathrm{pH}$ and rock cover increased from the ridge to the valley site, but decreased with altitude. Thus, the percentage of soil $\mathrm{pH}$ and rock cover decreased as elevation increased. The rock cover at the valley site exceeded that at the ridge site, possibly due to rocks accumulating in the valley. The lowest species diversity and abundance of liana species were found at the ridge site (Fig. 2), suggesting that, along the topographic gradient, rock cover at the valley site might facilitate better soil drainage, which, when combined with the with lower soil $\mathrm{pH}$, favoured liana diversity.

Liana species diversity gradually increases at lower elevations (below 1,000 m), is highest at intermediate elevations (1,000-2,000 m) and decreases rapidly as altitude increases (above 2,500-3,000 m), at least in Taiwan (Ho 1996). The elevations in our study area range from 180 to $900 \mathrm{~m}$ a.s.l., and the distribution of liana species was, indeed, related to altitude; however, the species richness of lianas decreased as altitude increased (Table 6). 
The climbing mechanisms of lianas was related to the DBH of host trees. For instance, the growth of stemtwining lianas was limited by the DBH of host trees (Putz and Holbrook 1991; DeWalt et al. 2000). Our study also showed that adhering lianas climb large host trees more easily than stem-twining or leaning-hook lianas (Fig. 5). At our study location, the density of adhesive lianas exceeded that of any other climbing type. In particular, Psychotria serpens (Rubiaceae), Piper taiwanense (Piperaceae) and Trachelospermum gracilipes (Apocynaceae) were present in almost all plots (Table 2). The adhesive structure of lianas, including adventitious roots and disks, appeared to increase the probability of climbing success. Further sampling should be conducted to examine this phenomenon.

As lianas are not self-standing, their ability to climb trees to reach the canopy affects their growth and development and indirectly influences their DBH (Nabe-Neilsen 2004). The structural parasitism of host trees by lianas might be affected by other factors in addition to the DBH of host trees. As trees with a larger DBH have been growing for a longer time, there may have been more opportunities for lianas to climb them; however, the species diversity and abundance of lianas and interspecific interactions might be more important features than the DBH of host trees with regard to liana growth on trees. The characteristics of coarse or smooth bark and presence of buttress roots (Leicht-Young et al. 2010) in trees might also affect the climbing ability of lianas.

\section{Conclusions}

Our results show that the distribution patterns of lianas and their species richness vary with topography and in relation to significant abiotic factors such as soil $\mathrm{pH}$ and rock cover. Overall, no lianas with a DBH greater than $10 \mathrm{~cm}$ were recorded in this study. The lianas with the largest DBH and the highest frequency were Kadsura japonica and Mussaenda pubescens, respectively. The average DBH of lianas was largest at the slope site, which was possibly related to the soil $\mathrm{pH}$ and rock cover. Larger lianas were found on larger host trees, while adhering lianas climbed significantly larger trees than lianas that used other climbing mechanisms. In conclusion, the climbing mechanisms of lianas might play an important role in the forest dynamics of tropical and subtropical areas.
Acknowledgements We thank the staff members of PPI Herbarium at the National Pingtung University of Science and Technology for monitoring the liana and vegetation plots and collecting the fresh stem specimens. We also thank the anonymous reviewers and the editor for providing valuable comments and insights that improved an earlier draft of this manuscript. This experiment complied with the current laws of Taiwan.

\section{Appendix 1 Lianas list in Tajen Experimental Forest Station, Taiwan}

1. Actinidiaceae

1. Actinidia callosa Lindl.

2. Annonaceae

2. Fissistigma glaucescens (Hance) Merr.

3. Apocynaceae

3. Anodendron affine (Hook. \& Arn.) Druce

4. Anodendron benthamiana Hemsl.

5. Ecdysanthera rosea Hook. \& Arn.

6. Melodinus angustifolius Hayata

7. Trachelospermum gracilipes Hook. f.

4. Araliaceae

8. Eleutherococcus trifoliatus (L.) S.Y. Hu

5. Aristolochiaceae

9. Aristolochia cucurbitifolia Hayata

10. Aristolochia foveolata Merr.

6. Asclepiadaceae

11. Cryptolepis sinensis (Lour.) Merr. Roem. \& Schultes

12. Hoya carnosa (L. f.) R. Br.

13. Marsdenia formosana Masamune

14. Marsdenia tinctoria $\mathrm{R}$. Br.

15. Tylophora taiwanensis Hatusima

7. Asteraceae

16. Mikania micrantha Kunth

8. Capparidaceae

17. Capparis sikkimensis Kurz subsp. formosana (Hemsl.) Jacobs

9. Celastraceae

18. Celastrus hindsii Benth.

19. Celastrus kusanoi Hayata

20. Celastrus punctatus Thunb.

10. Convolvulaceae

21. Erycibe henryi Prain

22. Ipomoea cairica (L.) Sweet

11. Cucurbitaceae

23. Diplocyclos palmatus (L.) C. Jeffrey

24. Trichosanthes cucumeroides (Seringe) Maxim. ex Fr. \& Sav. 
25. Trichosanthes homophylla Hayata

12. Elaeagnaceae

26. Elaeagnus glabra Thunb.

13. Fabaceae

27. Bauhinia championii Benth.

28. Derris laxiflora Benth.

29. Mucuna macrocarpa Wall.

30. Pueraria montana (Lour.) Merr.

14. Gesneriaceae

31. Aeschynanthus acuminatus Wall. ex A. DC.

15. Lardizabalaceae

32. Stauntonia obovata Hemsl.

33. Stauntonia obovatifoliola Hayata

16. Loganiaceae

34. Strychnos cathayensis Merr.

17. Malpighiaceae

35. Hiptage benghalensis (L.) Kurz

18. Menispermaceae

36. Cocculus orbiculatus (L.) DC.

37. Cyclea gracillima Diels

38. Pericampylus formosanus Diels

39. Stephania japonica (Thunb. ex Murray) Miers

40. Tinospora dentata Diels

19. Moraceae

41. Ficus aurantiaca Griff. var. parvifolia (Corner) Corner

42. Ficus pumila $\mathrm{L}$.

43. Ficus sarmentosa Buch.-Ham. ex J. E. Sm. var. nipponica (Fr. \& Sav.) Corner

44. Maclura cochinchinensis (Lour.) Corner

20. Nyctaginaceae

45. Pisonia aculeata $\mathrm{L}$.

21. Passifloraceae

46. Passiflora suberosa L.

22. Piperaceae

47. Piper kadsura (Choisy) Ohwi

48. Piper sintenense Hatusima

49. Piper taiwanense $\mathrm{Lin} \& \mathrm{Lu}$

23. Polygonaceae

50. Polygonum multiflorum Thunb. var. hypoleucum (Ohwi) Liu, Ying \& Lai

24. Ranunculaceae

51. Clematis akoensis Hayata

52. Clematis chinensis Osbeck

53. 53. Clematis uncinata Champ. ex Benth.

25. Rhamnaceae

54. Ventilago elegans Hemsl.

26. Rosaceae

55. Rubus pyrifolius J. E. Sm.
27. Rubiaceae

56. Coptosapelta diffusa (Champ. ex Benth.) Steen.

57. Morinda umbellata L.

58. Mussaenda pubescens Ait. f.

59. Paederia foetida $\mathrm{L}$.

60. Psychotria serpens L.

28. Rutaceae

61. Zanthoxylum nitidum (Roxb.) DC.

62. Zanthoxylum scandens Blume

29. Sabiaceae

63. Sabia swinhoei Hemsl.

30. Saxifragaceae

64. Pileostegia viburnoides Hook. f. \& Thoms.

31. Schisandraceae

65. Kadsura japonica (L.) Dunal

32. Vitaceae

66. Ampelopsis glandulosa (Wall.) Mom. var. hancei (Planch.) Mom.

67. Cayratia japonica (Thunb.) Gagnep.

68. Tetrastigma formosanum (Hemsl.) Gagnep.

69. Tetrastigma umbellatum (Hemsl.) Nakai

Monocotyledon

1. Arecaceae

70. Calamus formosanus Becc.

2. Dioscoreaceae

71. Dioscorea benthamii Prain \& Burk.

72. Dioscorea japonica Thunb.

73. Dioscorea matsudae Hayata

3. Flagellariaceae

74. Flagellaria indica $\mathrm{L}$.

4. Pandanaceae

75. Freycinetia formosana Hemsl.

5. Poaceae

76. Schizostachyum diffusum (Blanco) Merr.

6. Smilacaceae

77. Heterosmilax indica A. DC.

78. Smilax bracteata Presl var. verruculosa (Merr.) T. Koyama

79. Smilax china L.

80. Smilax corbularia Kunth

81. Smilax lanceifolia Roxb.

82. Smilax ocreata A. DC.

83. Smilax riparia A. DC.

7. Stemonaceae

84. Stemona tuberosa Lour. 
Open Access This article is distributed under the terms of the Creative Commons Attribution 4.0 International License (http:// creativecommons.org/licenses/by/4.0/), which permits unrestricted use, distribution, and reproduction in any medium, provided you give appropriate credit to the original author(s) and the source, provide a link to the Creative Commons license, and indicate if changes were made.

\section{References}

Addo-Fordjour P, Obeng S, Addo MG, Akyeampong S (2009) Effects of human disturbances and plant invasion on liana community structure and relationship with trees in the Tinte Bepo forest reserve, Ghana. Forest Ecol Managem 258:728-734

Boufford DE, Ohadhi H, Huang TC, Hsieh CF, Tsai JL, Yang KY (2003) A checklist of the vascular plants of Taiwan. In Boufford DE, Hsieh CF, Huang TC, Kuoh CS, Ohadhi H, Peng CI (eds) Flora of Taiwan. National Taiwan University Press, Taipei, Taiwan, pp 18-139

Bray RH, Kurtz LT (1945) Determination of total, organic, and available forms of phosphorus in soils. Soil Sci 59:39-45

Day FP, Monk CD (1974) Vegetation pattern on a southern Appalachian Watershed. Ecology 55:1064-1074

DeWalt SJ, Schnizer SA, Denslow JS (2000) Density and diversity of lianas along a chronosequence in a central Panamanian lowland forest. J Trop Ecol 16:1-19

Hegarty EE, Caballé G (1991) Distribution and abundance in forest communities. In Putz FE, Mooney HA (eds) The biology of vines. Cambridge University Press, Cambridge, UK. pp 313-335

Ho CC (1996) The relationship between the distribution and vegetation types of Taiwan. Masters thesis. National Taiwan University, Taiwan [in Chinese with English abstract]

Homeier J, Emglert F, Leuschner C, Weigelt P, Unger M (2010) Factors controlling the abundance of lianas along an altitudinal transect of tropical forests in Ecuador. Forest Ecol Managem 259:1399-1405

Isnard S, Silk WK (2009) Moving with climbing plants from Charles Darwin's time into the 21st century. Amer J Bot 96 : 1205-1221

Leicht-Young SA, Pavlovic NB, Frohnapple KJ, Grundel R (2010) Liana habitat and host preferences in northern temperate forests. Forest Ecol Managem 260:1467-1477

Letcher SG, Chazdon RL (2009) Lianas and self-supporting plants during tropical forest succession. Forest Ecol Managem 257: $2150-2156$
Malizia A, Grau HR, Lichstein JW (2009) Soil phosphorus and disturbance influence liana communities in a subtropical montane forest. J Veg Sci 21:551-560

Magurran AE (1988) Ecological diversity and its measurement. Croom Helm Ltd, Great Britain

Nabe-Neilsen J (2004) Demography of Machaerium cuspidatum, a shade-tolerant neotropical liana. J Trop Ecol 20:505-516

Norusis MJ (2011) PASW Statistics 20 guide to data analysis. Baker and Taylor Books, Charlotte, NC, USA

Nurfazliza K, Nizam MS, Nur Supardi MN (2012) Association of liana communities with their soil properties in a lowland forest of Negeri Sembilan, Peninsular Malaysia. Sains Malaysiana 41:679-690

Parthasarathy N, Muthuramkumar S, Reddy MS (2004) Patterns of liana diversity in tropical evergreen forests of peninsular India. Forest Ecol Managem 190:15-31

Putz FE (1983) Liana biomass and leaf area of a tierra firme forest in the Rio Negro Basin, Venezuela. Biotropica 15:185-189

Putz FE (1984) The natural history of lianas on Barro Colorado Island, Panama. Ecology 65:1713-1724

Putz FE, Holbrook NM (1991) Biomechanical studies of vines. In Putz FE, Mooney HA (eds) The Biology of vines. Cambridge University Press, Cambridge, UK, pp 73-97

Schnitzer SA (2005) A mechanistic explanation for global patterns of liana abundance and distribution. Amer Naturalist 166:262-276

Schnitzer SA, Bongers F (2002) The ecology of lianas and their role in forests. Trends Ecol Evol 17:223-230

Schnitzer SA, Bongers F (2011) Increasing liana abundance and biomass in tropical forests: emerging patterns and putative mechanisms. Ecol Letters 14:397-406

Schnitzer SA, DeWalt SJ, Chave J (2006) Censusing and measuring lianas: a quantitative comparison of the common methods. Biotropica 38:581-591

Tang Y, Kitching RL, Cao M (2012) Lianas as structural parasites: a re-evaluation. Chin Sci Bull 57:307-312

ter Braak CJF, Šmilauer P (2012) Canoco reference manual and user's guide: software for ordination (version 5.0). Microcomputer Power, Ithaca, $496 \mathrm{pp}$

van der Maarel E (1979) Transformation of cover-abundance values in phytosociology and its effect on community similarity. Vegetatio 39:97-114

Wright SJ, Hernandez A, Condit R (2007) The bushmeat harvest alters seedling banks by favoring lianas, large seeds, and seeds dispersed by bats, birds, and wind. Biotropica 39:363-371

Yang SZ, Chang SC, Lin YJ, Li CF (2015) Vegetation classification of lower montane secondary forest in southeastern Taiwan. Quart J Chin Forest 48:17-54 [in Chinese with English abstract] 